\title{
Influence of Soil Chemical Characteristics on the Nutritional Value of Morama (Tylosema esculentum) Bean Seed a Potential Crop in Botswana
}

\author{
Gaebewe M. Ramolemana ${ }^{1}$ \\ ${ }^{1}$ Department of Crop Science, Botswana College of Agriculture, Botswana \\ Correspondence: Gaebewe M. Ramolemana, Department of Crop Science, Botswana College of Agriculture, \\ Botswana. E-mail: gaebewe.ramolemana@mopipi.ub.bw, gaebewe@gmail.com
}

Received: March 7, 2013 Accepted: April 26, 2013 Online Published: May15, 2013

doi:10.5539/jas.v5n6p185 URL: http://dx.doi.org/10.5539/jas.v5n6p185

\begin{abstract}
Morama bean (Tylosema esculentum) is found wild in the Kgalagadi sands of Botswana, Namibia and some parts of South Africa. Morama plants were cultivated at Botswana College of Agriculture (BCA) in 2001 in a sandy loam soil which are producing seeds. The nutritional value of seed from a sandy loam soil (BCA) was compared to that of wild plants growing in a sandy soil and collected from Letlhakane in northern central region of Botswana. The effect of seed size on the nutritional value was also assessed. The results showed that ash, protein and potassium (K) contents were low by $12 \%, 9 \%$, and $20 \%$, respectively, for seeds from a sandy soil compared to those from a sandy loam soil. Calcium concentration was $40 \%$ high for seed from a sandy soil compared to a sandy loam soil. Phosphorus was not significantly affected by the soil type. Seed size significantly $(\mathrm{P}<0.05)$ affected fibre, ash, $\mathrm{P}, \mathrm{Ca}$ and $\mathrm{K}$ contents while moisture, fat and protein were not affected. Soil chemical properties and seed size influenced the nutritional value of morama bean seed. Phosphorus, calcium and potassium fertilizer application to poor soils will improve nutritional value of morama bean seed.
\end{abstract}

Keywords: morama, seed size, nutritional value, sandy loam, sandy soil

\section{Introduction}

Morama plants (Tylosema esculentum) are found wild in Kgalagadi sands of Botswana and Namibia and some parts of South Africa. The seeds are known to contain 30-39\% protein and 34-43\% fat (Holse, Husted, \& Hansen, 2010; National Academy of Sciences, 1979). Morama was reported to be a non-nodulating legume that depends on soil nitrogen to meet its requirements (Dakora, Lawlor, \& Sibuga, 1999). Mitchell, Keys, Madgwick \& Lawlor (2005) reported that morama bean has photosynthetic characteristics similar to other $\mathrm{C}_{3}$ plants. In a field experiment conducted in Botswana, morama did not respond to phosphorus and nitrogen fertilization (Ramolemana, Machacha, Lebutswe, \& Tsopito, 2003). The soils in areas where marama grows are relatively poor in mineral nutrients compared to soils where it is not found growing (Ramolemana Machacha, Lebutswe, Tsopito, Mosekiemang, \& Tekane, 2007). The plant seems to have capacity to extract nutrients from poor soils to meet its requirement for shoot growth and seed development. The concentrations of $\mathrm{N}, \mathrm{P}, \mathrm{K}, \mathrm{Ca}$, and $\mathrm{Mg}$ in morama sprouts of both cultivated and wild plants were found to be the same (Ramolemana et al., 2003, 2007). The seed and young tubers collected from the wild are usually roasted and eaten as snack. Amaerteifio \& Moholo (1998) analyzed morama seed collected from Botswana and found it to contain 3.7\% ash; $33.5 \%$ crude fat; $34.1 \%$ crude protein; $4.4 \%$ crude fibre; $7760 \mathrm{mg} / \mathrm{kg} \mathrm{K} ; 3970 \mathrm{mg} / \mathrm{kg} \mathrm{P}$ and $1520 \mathrm{mg} / \mathrm{kg} \mathrm{Ca}$. In that study, morama seed was found to contain more $\mathrm{Ca}$ and $\mathrm{P}$ than that of Bambara groundnut (Vigna subterranean), mung bean (Vigna radiate) and tepary bean (Phaseolus acutifolius). Holse et al. (2010) reported that in general morama seed from South Africa had higher content of protein and ash compared to beans from Botswan and Namibia and atttributed the differences to climate and soils. Maruatona, Duodu and Minnar (2010) reported high levels of tyrosine in morama bean flours. They also concluded that due to its high protein contents, morama bean flours could be used to increase the protein quality of cereal based foods to help alleviate protein-energy nutrition in sub-Sahara Africa.

Morama bean can be an important source of protein for the growing population of the world and efforts should be made to grow it commercially. The oil from the seed can also be evaluated for use in automobiles as one of the bio-fuels that can replace the fossil fuels that pollute our environment. In previous studies (Ramolemana et al., 
$2003,2007)$ plant materials for both planted and wild plants were evaluated and seed material was not evaluated. The objectives of this study were to evaluate the influence of soil type on the nutritional value of morama bean seed; and to evaluate the effect of seed size on the nutritional value of morama bean seed.

\section{Materials and Methods}

Seed of wild morama plants was collected from Letlhakane $\left(21^{\circ} 34^{\prime} \mathrm{S} ; 25^{\circ} 42^{\prime} \mathrm{E}\right)$ Botswana growing on a Kalahari sandy soil and the other seed was collected from cultivated morama plants at Sebele (24 $33^{\prime} \mathrm{S} ; 25^{\circ} 54^{\prime} ; 994 \mathrm{~m}$ ) Botswana growing on a sandy loam soil. The cultivated plants were established in the year 2000 and were fertilized with single super phosphate and urea between year 2000 and 2002 (Ramolemana et al., 2003). Some chemical characteristics of soils where the seeds were collected are given in Table 1 with the sandy loam soil and sandy soil described in Ramolemana et al. (2003) and Ramolemana et al. (2007), respectively. The seeds collected from the sandy soil and sandy loam soil, were a composite from many plants growing on those soil types. The seeds from the two soil types were sorted into three sizes; small (1.0-1.9 g), medium (2.0-2.9) and large ( $>3.0 \mathrm{~g})$. For each seed size, three replicates of 50 seeds were shelled (de-hulled) and ground in a steel mill through a $2 \mathrm{~mm}$ sieve to make a composite sample. The composite samples were analyzed in triplicates. The samples were analyzed at the National Food Technology Research Centre in Kanye, Botswana using the Association of Analytical Chemists (AOAC) Method 2001.

Table1. Some soil chemical characteristics where morama bean seeds were collected

\begin{tabular}{lllllllll}
\hline & $\begin{array}{l}\mathrm{pH} \\
\left(\mathrm{CaCl}_{2}\right)\end{array}$ & $\begin{array}{l}\mathrm{P} \\
(\mathrm{mg} / \mathrm{kg})\end{array}$ & $\begin{array}{l}\text { Org. } \\
(\% \mathrm{Wt})\end{array}$ & $\begin{array}{l}\mathrm{Ca} \\
(\mathrm{cmol} / \mathrm{kg})\end{array}$ & $\begin{array}{l}\mathrm{Mg} \\
(\mathrm{cmol} / \mathrm{kg})\end{array}$ & $\begin{array}{l}\mathrm{K} \\
(\mathrm{cmol} / \mathrm{kg})\end{array}$ & $\begin{array}{l}\mathrm{Na} \\
(\mathrm{cmol} / \mathrm{kg})\end{array}$ & $\begin{array}{l}\mathrm{CEC} \\
(\mathrm{cmol} / \mathrm{kg})\end{array}$ \\
\hline $\begin{array}{l}\text { Sandy } \\
\text { loam }\end{array}$ & 4.72 & 5.2 & 0.40 & 1.29 & 0.65 & 0.76 & 0.17 & 4.60 \\
Sandy & 8.31 & 0.02 & 0.02 & 1.88 & 0.21 & 0.08 & 0.08 & 4.06 \\
\hline
\end{tabular}

The parameters determined were as follows: moisture using the AOAC 934.01 method; crude fat by AOAC 960.39 method; crude fibre by AOAC 962.09 method (Crude fibre in animal feed and pet food), ash by AOAC 923.03 method; protein by Dumas combustion (AOAC 992.23 method: Crude protein in cereal grains and oilseeds), phosphorus by AOAC 995.11 method; calcium, potassium and iron were by AOAC 999.10 method.

The data was subjected to ANOVA using GLM Procedure of SAS (2004) progamme. Means which were significantly different were separated using LSD.

\section{Results}

\subsection{Effect of Soil Type}

The moisture content of seed was significantly $(\mathrm{P}<0.0001)$ affected by the soil type (Table 2$)$. The moisture content of the seed from the sandy soil was $16 \%$ high compared to that from a sandy loam soil. The fat and fibre contents of the seeds were not significantly affected by the soil type.

Table 2. Effect of soil type on the nutritional value of morama bean seed

\begin{tabular}{llllllllll}
\hline Soil Type & $\begin{array}{l}\text { MC } \\
(\%)\end{array}$ & $\begin{array}{l}\text { Fat } \\
(\%)\end{array}$ & Fibre (\%) & $\begin{array}{l}\text { Ash } \\
(\%)\end{array}$ & Protein $(\%)$ & $\mathrm{P}(\mathrm{mg} / \mathrm{kg})$ & $\mathrm{Ca}(\mathrm{mg} / \mathrm{kg})$ & $\mathrm{K}(\mathrm{mg} / \mathrm{kg})$ & $\begin{array}{l}\mathrm{Fe} \\
(\mathrm{mg} / \mathrm{kg})\end{array}$ \\
\hline Sandy $^{1}$ & $5.80 \mathrm{a}$ & $41.71 \mathrm{a}$ & $2.19 \mathrm{a}$ & $2.98 \mathrm{~b}$ & $37.90 \mathrm{~b}$ & $3427 \mathrm{a}$ & $1765 \mathrm{a}$ & $7508 \mathrm{~b}$ & $62.19 \mathrm{a}$ \\
Sandy loam $^{2}$ & $4.99 \mathrm{~b}$ & $41.18 \mathrm{a}$ & $1.99 \mathrm{a}$ & $3.34 \mathrm{a}$ & $41.26 \mathrm{a}$ & $3672 \mathrm{a}$ & $1260 \mathrm{~b}$ & $9033 \mathrm{a}$ & $75.08 \mathrm{a}$ \\
P-Level & $<0.0001$ & $\mathrm{NS}$ & $\mathrm{NS}$ & $<0.0001$ & $<0.05$ & $\mathrm{NS}$ & $<0.0001$ & $<0.0001$ & $\mathrm{NS}$ \\
LSD & 0.28 & 1.01 & 0.45 & 0.05 & 2.53 & 491 & 92.9 & 472 & 17.25 \\
\hline
\end{tabular}

Note: 1 = Seed from wild plants; 2 = Seed from cultivated plants; NS = not significant.

NB: Carbohydrates (\%) are by computation.

The ash content of the seeds were significantly $(\mathrm{P}<0.001)$ different (Table 2$)$. The ash content of seed from a sandy loam soil was $12 \%$ high compared to that from a sandy soil. 
The protein content of the seeds was significantly $(\mathrm{P}<0.05)$ different with that from a sandy loam soil high compared to that from a sandy soil (Table 2). The protein content of seed from a sandy loam was $9 \%$ high compared to that from a sandy soil.

Phosphorus and iron contents of the seeds were not significantly affected by soil type (Table 2). Calcium and potassium were significantly $(\mathrm{P}<0.001)$ affected by the soil type (Table 2$)$. The $\mathrm{Ca}$ in seeds from a sandy soil was $40 \%$ high compared to those from a sandy loam soil. The $\mathrm{K}$ in seeds from a sandy loam soil was $20 \%$ high compared to those from a sandy soil.

\subsection{Effect of Seed Size}

Moisture, fat and protein contents were not significantly affected by seed size (Table 3).

Table3. Effect of seed size on the nutritional value of morama bean seed

\begin{tabular}{llllllllll}
\hline $\begin{array}{l}\text { Seed } \\
\text { size }\end{array}$ & $\begin{array}{l}\mathrm{MC} \\
(\%)\end{array}$ & $\begin{array}{l}\text { Fat } \\
(\%)\end{array}$ & $\begin{array}{l}\text { Fibre } \\
(\%)\end{array}$ & $\begin{array}{l}\text { Ash } \\
(\%)\end{array}$ & $\begin{array}{l}\text { Protein } \\
(\%)\end{array}$ & $\begin{array}{l}\mathrm{P} \\
(\mathrm{mg} / \mathrm{kg})\end{array}$ & $\begin{array}{l}\mathrm{Ca} \\
(\mathrm{mg} / \mathrm{kg})\end{array}$ & $\begin{array}{l}\mathrm{K} \\
(\mathrm{mg} / \mathrm{kg})\end{array}$ & $\begin{array}{l}\mathrm{Fe} \\
(\mathrm{mg} / \mathrm{kg})\end{array}$ \\
\hline Small & $5.48 \mathrm{a}$ & $40.73 \mathrm{a}$ & $2.18 \mathrm{ab}$ & $3.22 \mathrm{a}$ & $41.42 \mathrm{a}$ & $3764 \mathrm{a}$ & 1743 & $8059 \mathrm{~b}$ & $67.32 \mathrm{ab}$ \\
Medium & $5.47 \mathrm{a}$ & $41.78 \mathrm{a}$ & $2.42 \mathrm{a}$ & $3.15 \mathrm{~b}$ & $38.48 \mathrm{a}$ & $3746 \mathrm{a}$ & 1472 & $8072 \mathrm{~b}$ & $55.98 \mathrm{~b}$ \\
Large & $5.23 \mathrm{a}$ & $41.82 \mathrm{a}$ & $1.67 \mathrm{~b}$ & $3.12 \mathrm{~b}$ & $38.83 \mathrm{a}$ & $3139 \mathrm{~b}$ & 1323 & $8680 \mathrm{a}$ & $82.6 \mathrm{a}$ \\
P-Level & $\mathrm{NS}$ & $\mathrm{NS}$ & $<0.05$ & $<0.01$ & $\mathrm{NS}$ & $<0.05$ & $<0.0001$ & $<0.05$ & $\mathrm{NS}$ \\
LSD & 0.35 & 1.24 & 0.55 & 0.06 & 3.10 & 602 & 113.7 & 578 & 21.12 \\
\hline
\end{tabular}

$\mathrm{NS}=$ not significant.

NB: Carbohydrates (\%) are by computation.

Fibre of large seed was significantly $(\mathrm{P}<0.05)$ low compared to medium size seed (Table 3$)$. The fibre for medium seed was $45 \%$ high compared to large seed.

Ash content for medium and large seed sizes were significantly $(\mathrm{P}<0.01)$ low compared to small seed (Table 3 ). Small seed ash was $3 \%$ high compared to large seed.

Phosphorus concentration of the seed was significantly $(\mathrm{P}<0.05)$ affected by seed size (Table 3$)$. The $\mathrm{P}$ concentration of small seed was $20 \%$ high compared to that of large seed. The Ca concentration was significantly $(\mathrm{P}<0.0001)$ affected by seed size (Table 3$)$. The seed sizes were significantly $(\mathrm{P}<0.05)$ different with the small seed having the highest $\mathrm{Ca}$ concentration and large seed the lowest concentration. The Ca concentration of the small seed was $32 \%$ high compared to that of large seed. The Ca concentration of the small seed was $18 \%$ high compared to that of medium seed.

Potassium concentration was significantly $(\mathrm{P}<0.05)$ affected by seed size (Table 3$)$. The $\mathrm{K}$ concentration of large seed was $8 \%$ high compared to that of small seed.

\section{Discussion}

Curtin, Syers and Bolan, (1993) observed that the magnitude of the soil $\mathrm{pH}$ effect on desorption of nutrient elements depends on the composition of exchangeable cation suite. Specifically, P desorption is less sensitive to $\mathrm{pH}$ when cation exchange sites are occupied by $\mathrm{Ca}\left({ }^{++}\right)$than when a monovalent cation $\left(^{+}\right)$is present. The soil chemical characteristics in this study show that the P concentration of the sandy loam soil was 260 times high compared to a sandy soil and yet there was no significant difference in the $\mathrm{P}$ accumulation of seed from the two soil types (Tables 1 and 2). However, the sandy soil had a relatively high Ca concentration compared to the sandy loam soil and this may have been responsible for desorption of $\mathrm{P}$ from the soil to meet the $\mathrm{P}$ requirements of the seed. The $\mathrm{P}$ seed accumulation under low soil $\mathrm{P}$ content may imply that morama plants have an efficient $\mathrm{P}$ uptake and seed $\mathrm{P}$ accumulation mechanism. Morama did not respond to $\mathrm{P}$ and $\mathrm{N}$ fertilization in a sandy loam soil (Ramolemana et al., 2003). The high P uptake has also been observed for some plants growing in low $\mathrm{P}$ soils (Ramolemana, Keltjens, Wessel, \& Maphanyane, 2002). The sandy loam soil had a relatively high K (monovalent cation) concentration compared to the sandy soil (high Ca- divalent), and this may have hindered the $\mathrm{P}$ desorption from the soil to increase $\mathrm{P}$ uptake under the relatively high soil $\mathrm{P}$ content. The relatively poor $\mathrm{P}$ uptake in the sandy loam soil may be explained by the effect of the relatively high $\mathrm{K}$ (monovalent cation) content as reported by Curtin, et al. (1993). This may mean that liming acid soils to increase Ca may benefit morama bean seed and improve seed $\mathrm{P}$ accumulation. The seed $\mathrm{Ca}$ accumulation from a sandy soil was $40 \%$ high compared to that from a sandy loam soil, yet the soil Ca concentration of sandy soil was about 1.5 times that of a sandy loam. The sandy soil had 23.5 
times $\mathrm{Ca}$ to $\mathrm{K}$ while sandy loam soil had $1.7 \mathrm{Ca}$ to $\mathrm{K}$. The high soil Ca concentration in sandy soil increased seed $\mathrm{Ca}$ and may have also benefited seed $\mathrm{P}$ accumulation which was as high as seed from soil with relatively high $\mathrm{P}$ concentration. This has implication on the nutritional value of food products developed from seed from soils high in $\mathrm{Ca}$. The products such as morama milk and flour will be rich in $\mathrm{Ca}$ and $\mathrm{P}$ (Maruatona et al., 2010)

The sandy loam soil only increased the seed $\mathrm{K}$ accumulation by $20 \%$ but had 9.5 times high $\mathrm{K}$ concentration compared to a sandy soil. This may be an indication that morama plants have the capacity to absorb and accumulate in its seed mineral elements that have a low concentration in soils.

Seed Fe concentration would be expected to be high for sandy loam soil with a $\mathrm{pH}$ of 4.72 but there was no significant difference compared to a sandy soil with $\mathrm{pH}$ 8.31. Under low $\mathrm{pH}$ conditions Fe solubility and availability is usually high and solubility is low under high $\mathrm{pH}$ conditions. Therefore morama seed growing in high $\mathrm{pH}$ soils is able to accumulate Fe levels similar to those grown on low $\mathrm{pH}$ soils where Fe solubility is high. This makes morama seed a very good source of Fe for human beings and other animals. The Fe levels in this study were slightly higher than those reported by Amarteifio and Moholo (1998).

Small seed had significantly high P and Ca concentrations compared to large seed (Table 3 ). However, the K concentration of small seed was low compared to that of large seed. Small seed, with a high $\mathrm{Ca}$ and $\mathrm{P}$ concentrations, will make high quality morama food products. It should be noted that small seeds have reduced dry matter accumulation resulting in an increase in the concentration of mineral nutrients in seeds. This was observed in soya bean seed by Samarah, Mullen and Cianzio (2004). Small seed had significantly more fibre and ash than large seed (Table 3). The fibre was $31 \%$ high for small seed compared to large seed. Therefore small seed is more nutritious than large seed. Morama plants were found to have low seed rates and breeding for small seeds may improve the seed rate and nutritional value (Ramolemana et al., 2007; Hartley, Tshamekang, \& Thomas, 2002).

\section{Conclusions}

Soil type had significant effect on the nutritional value of morama seed. Phosphorus, $\mathrm{Ca}$ and $\mathrm{K}$ containing fertilizers will improve the nutritional value of morama bean seed. Small seeds had more fibre, ash, $\mathrm{P}$, and $\mathrm{Ca}$ and therefore more nutritious than large seed. Breeding or selection for small seed may improve the nutritional value of morama bean seed.

\section{Acknowledgement}

This study is part of the work under the EU funded Morama Bean Project. Contract No IC4-CT-2000-30010. The author would also like to thank Botswana College of Agriculture for its support of the Morama Bean Project. I would also like to thank Professor V. Emongor for assisting with the statistical analysis.

\section{References}

Association of Official Analytical Chemists (AOAC). (2001). Official methods of analysis of Association of Official Analytical Chemists. Washington, DC: AOAC International.

Amarteifio, J. O., \& Moholo, D. (1998). The chemical composition of four legumes consumed in Botswana. Journal of Food Composition and Analysis, 11, 329-332. http://dx.doi.org/10.1006/jfca.1998.0595

Curtin, D., Syers, J. K., \& Bolan, N. S. (1993). Phosphate sorption by soil in relation to exchangeable cation composition and pH. Australian Journal of Soil Research, 31(2), 137-149. http://dx.doi.org/10.1071/SR9930137

Dakora, F. D., Lawlor, D. W., \& Sibuga, K. P. (1999). Assessment of symbiotic nitrogen nutrition in marama bean (Tylosema esculentum L.) a Tuber-producing underutilized African grain legume. Symbiosis, 27, 269-277.

Hartley, M. L., Tshamekang, E., \& Thomas, S. M. (2002). Functional Heterostyly in Tylosema esculentum (Caesalpinioideae). Annals of Botany, 89, 67-72. http://dx.doi.org/10.1093/aob.mcf006

Holse, M., Husted, S., \& Hansen, A. (2010). Chemical Composition of morama bean (Tylosema esculenyum) - A wild African bean with unexploited potential. Journal of Food Composition and Analysis, 23, 648-657. http://dx.doi.org/10.1016/jfca.2010.03.006

Maruatona, N. M., Duodu, K. G., \& Minnar, A. (2010). Physiochemical, nutritional and functional properties of marama bean flour. Food Chemistry, 121, 400-405. http://dx.doi.org/10.1016/j.foodchem.12.054

Mitchell, R. A. C., Keys, A. J., Madgwick, P. J., Parry, M. A. J., \& Lawlor, D. W. (2005). Adaptation of photosynthesis in marama bean (Tylosema esculentum (Burchell A. Schreiber) to a high temperature, high radiation, drought-prone environment. Plant Physiology and Biochemistry, 43, 969-976. Hptt://dx.doi.org/10.1016/j.plphy.2005.08.009 
National Academy of Sciences. (1979). Tropical Legumes: Resources for the Future. Washington DC.

Ramolemana, G. M., Keltjens, W. G., Wessel, M., \& Maphanyane, G. S. (2002). Phosphorus levels in shoots of Bambara groundnut in Botswana soils. Journal of Plant Nutrition, 25(9), 2035-2049. http://dx.doi.org/10.1081/PLN-120013293

Ramolemana, G. M., Machacha, S., Lebutswe, T., \& Tsopito, C. M. (2003). Response of morama bean (Tylosema esculentum, Burch) to phosphorus and nitrogen fertilization in a sandy loam soil at Sebele, Botswana. UNISWA Journal of Agriculture, 11, 34-39. Retrieved from www.ajol.info/index.php/uniswa/article/viewFile/4625/12309

Ramolemana, G. M., Machacha, S., Lebutswe, T., Mosekiemang, T., \& Tekane, O. (2007). Growth characteristic and mineral content of wild marama bean (Tylosema esculentum, Burch) plants in Botswana. Botswana Journal of Agriculture and Applied Sciences, 3(1), 67-72.

Samarah, N., Mullen, R., \& Cianzio, S. (2004). Size distribution and mineral nutrients of soybean seeds in response to drought stress. Journal of Plant Nutrition, 27(5), 815-835. http://dx.doi.org/10.1081/PLN-120030673

SAS. (2004). Statistical Analysis Systems User's Guide. Cary NC USA: SAS Institute Inc. 